\title{
Feeding rate of the oyster Crassostrea gigas in a natural planktonic community of the Mediterranean Thau Lagoon
}

\author{
Christine Dupuy ${ }^{1,2, *}$ André Vaquer ${ }^{3}$, Thong Lam-Höai ${ }^{3}$, Claude Rougier ${ }^{3}$, \\ Nabila Mazouni ${ }^{4}$, Jacques Lautier ${ }^{3}$, Yves Collos ${ }^{3}$, Solange Le Gall ${ }^{1}$ \\ ${ }^{1}$ CNRS/IFREMER, UMR 10, CREMA L'Houmeau, BP 5, 17137, L'Houmeau, France \\ ${ }^{2}$ LBEM, Université de La Rochelle, EA 3168 Pôle Science Av. Michel crépeau, 17042 La Rochelle, France \\ ${ }^{3}$ Laboratoire d'Hydrobiologie, UMR 5556 and URM 5, Université Montpellier II, 34095 Montpellier Cedex 05, France \\ ${ }^{4}$ IFREMER-Sète, BP 171, 34203 Sète, France
}

\begin{abstract}
The Mediterranean Thau Lagoon is an important oyster farming area in Europe. Oyster growth rates are among the highest in France, although chlorophyll a concentration is low. Previous studies have demonstrated that picophytoplankton, nano-microphytoplankton, dinoflagellates and loricate ciliates such as tintinnids are abundant. However, heterotrophic flagellates and aloricate ciliates have not been investigated. The aim of this study was to assess picophytoplankton, protist and zooplankton abundances in the Lagoon and to investigate the particular structure of the microbial food web, which may explain such paradoxical oyster growth. In oligotrophic waters in the Thau Lagoon, the picoeukaryote Ostreococcus tauri is the dominant autotrophic picoplankter, with an abundance maximum in summer. On 17 August 1998, following a rainfall event, pico- and nanophytoplankton abundances were not as high as expected and we observed a high abundance of large diatoms. At this time, the available carbon resources were produced by microphytoplankton $(84.5 \%)$, and picoplanktonic cells represented only $1.27 \%$ in terms of carbon. Heterotrophic cells were low in abundance and constituted $<14 \%$ of carbon resources. In order to evaluate the importance of the 'protozoan trophic link' for energy transfer from the microbial food web to large benthic suspension feeders, the oyster Crassostrea gigas was offered a planktonic community as potential prey. In the grazing experiment, all $>5 \mu \mathrm{m}$ flagellates, microphytoplankton, dinoflagellates, ciliates and large zooplankton were retained by the oyster gills. Only flagellates $<5 \mu \mathrm{m}$ and $O$. tauri were not very well retained (45 and $2 \%$ respectively). The high clearance rates of $C$. gigas found in this experiment can be explained by a low concentration of suspended particulate matter $\left(0.65 \mathrm{mg} \mathrm{l}^{-1}\right)$. The oysters adapted their retention mechanism when they lived in oligotrophic waters. These results indicate that, under the given experimental conditions, picophytoplankton did not represent a valuable trophic resource for farmed oysters because (1) C. gigas cannot retain picoparticles and (2) the picoplankton represented a poor carbon resource capable of being transferred via a weak heterotrophic protist community. In the oyster pens of the Thau Lagoon during this study, microphytoplanktonic primary producers, in particular diatoms, were the main food sources for bivalve suspension feeders.
\end{abstract}

KEY WORDS: Bivalve $\cdot$ Oyster $\cdot$ Food source $\cdot$ Thau Lagoon $\cdot$ Microbial food web $\cdot$ Heterotrophic protist $\cdot$ Picophytoplankton $\cdot$ Trophic link

Resale or republication not permitted without written consent of the publisher

\section{INTRODUCTION}

Oysters obtain energy resources by filtering particles from seawater, and their growth depends upon the

*E-mail: cdupuy@ifremer.fr nutritive value of the retained seston (Berg \& Newell 1986), which is related to the trophic capacity of coastal waters (Héral 1985). Marine lagoons can be considered individual entities to adjoining ecosystems. The Mediterranean Thau Lagoon is an important European oyster farming area, with standing stocks of Crassostrea 
gigas estimated at 40000 tons. Oyster growth levels are among the highest in France (Goyard 1995), although chlorophyll a concentration is low $\left(<2 \mu \mathrm{g}^{-1}\right.$, Frisoni 1984) compared to other coastal ecosystems. The particular structure of the Thau Lagoon microbial food web may explain such paradoxical oyster growth. In the oceans, more than $50 \%$ of the primary production is due to unicellular organisms $<3 \mu \mathrm{m}$ in size (Li et al. 1983, Platt et al. 1983, Glover et al. 1986), which constitute a nutrient source of particulate and dissolved organic matter for heterotrophic organisms. In the Thau Lagoon, Ostreococcus tauri, a picoeukaryote $<1 \mu \mathrm{m}$ in size, is responsible for most of the primary production in the summer (Courties et al. 1994). Furthermore, high levels of dissolved organic matter (DOM) in the Lagoon provide a potential for high bacterial production. However, such small picoparticles are not efficiently retained by the gills of bivalves, particularly oysters (<20\% for picoparticles; Shumway et al. 1985, Héral 1985, Riisgård 1988, Barillé et al. 1993).

Protists, which consume bacteria and phytoplankton, are abundant in coastal ecosystems (Revelante \& Gilmartin 1983, Sherr et al. 1986a, Fenchel 1988, Leakey et al. 1992). They are preyed upon by numerous organisms of zooplankton, particularly copepods (Berk et al. 1977, Jonsson \& Tiselius 1990, Gifford \& Dagg 1991, Hartmann et al. 1993) and thus have been suggested as a major trophic link between picoplank-

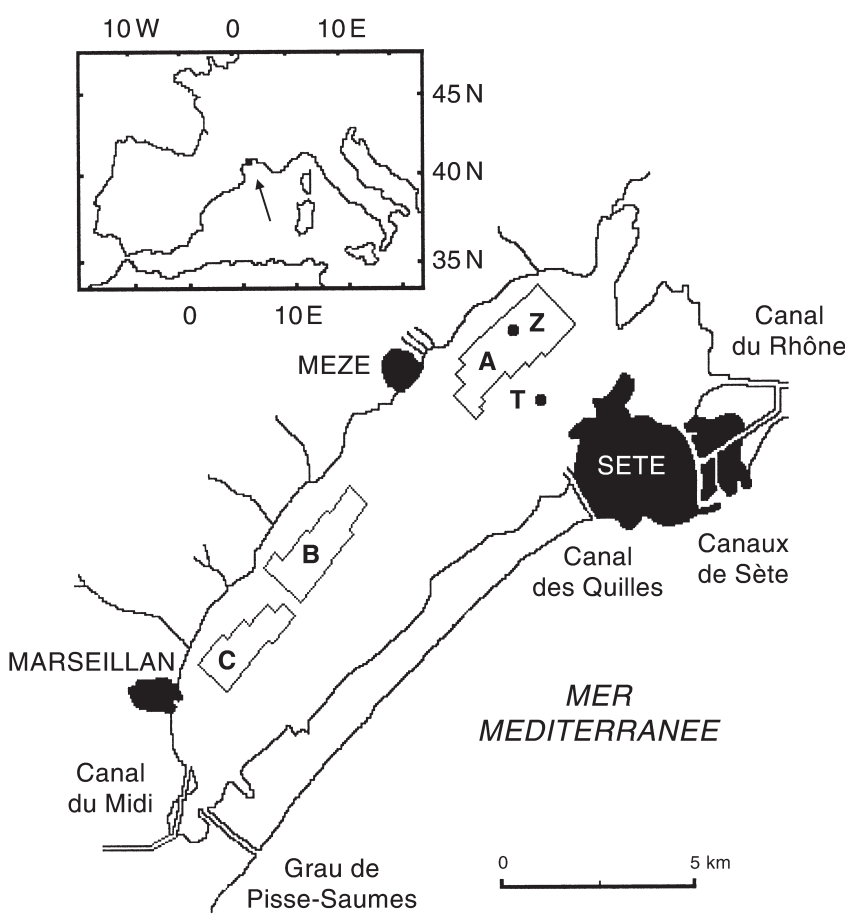

Fig. 1. Location of the sampling station (Stn Z) in Thau Lagoon. The station is inside the northern oyster farming area A (from Thong Lam Hoai) ton and micro- or macroplankton (Porter et al. 1979, Conover 1982, Sherr et al. 1986b, Stoecker \& Capuzzo 1990). Likewise, protists may represent a trophic link between picoplankton and filter-feeding bivalves. Some data support this assumption. Tintinnids have been observed in oysters' stomachs (Paulmier 1972). Moreover, filter-feeding benthic molluscs retain protists, as shown by contaminations of bivalves by toxic flagellates (Sournia et al. 1991). In a mixed cell suspension of phytoplankton and dinoflagellates, 6 different species of bivalves were able to selectively clear and digest dinoflagellates (Shumway et al. 1985). The mussel Geukensia demissa removed microbiota from a salt-marsh water column with different effectiveness according to the cell type (Kemp et al. 1990). Crassostrea gigas easily consumed a non-toxic microdinoflagellate (Bardouil et al. 1996). Ingestion and assimilation of bacterial carbon via heterotrophic flagellates were demonstrated in mussels (Kreeger \& Newell 1996). Similarly, C. gigas retained and ingested a cultured bacterivorous ciliate, Uronema sp. (Le Gall et al. 1997). In a French Atlantic coastal oyster pond, the field community of hetero-/mixotrophic protists was $90 \%$ retained and represented the main energy resource for oysters (Dupuy et al. 1999). Heterotrophic protists may thus constitute an alternative or complementary food resource for oysters, allowing an indirect recovery of DOM and picoplanktonic production otherwise not accessible to them.

In the Thau Lagoon, loricate ciliates such as tintinnids are abundant (Lam-Hoai et al. 1997), but heterotrophic flagellates and aloricate ciliates have not previously been studied. The aim of this study was to assess picophytoplankton, protist and zooplankton abundances in the water column of the Thau Lagoon and investigate their potential use by oysters as a trophic resource. Specific questions to be addressed were: (1) Do the different microbiota from the planktonic community represent a substantial energy resource in the Thau Lagoon water columns? (2) Is oyster filtration effective enough to account for the removal of a sufficient trophic resource from cleared microbiota? Our experimental approach to studying the effect of oyster filtration on a planktonic field community was to monitor changes in the abundance of the different microbiota in a $1300 \mathrm{ml}$ tray, on a time scale of $30 \mathrm{~min}$.

\section{MATERIALS AND METHODS}

The Thau Lagoon (France, $3^{\circ} 36^{\prime} \mathrm{E}, 43^{\circ} 24^{\prime} \mathrm{N}$ ) has an area of $75 \mathrm{~km}^{2}$ and a mean depth of $5 \mathrm{~m}$, and is connected to the sea by 3 narrow channels. Shellfish breeding is carried out in 3 areas off the northwestern shore (Fig. 1). 
Oyster collection and acclimation. Oysters were collected in the middle of August 1998 from the NW farming area (Stn Z, Fig. 1) of the Thau Lagoon. Fifty adult Crassostrea gigas (1 yr old, shell length about $5 \mathrm{~cm}$ ) were transported to the laboratory, epibionts were removed and then the oysters were acclimatized overnight to the ambient field temperature of $25^{\circ} \mathrm{C}$, in GF/C $(1.2 \mu \mathrm{m}$, Whatman) filtered water. Just before the experiment, 10 actively filtering oysters were selected and only 3 were used to perform the retention experiments.

Planktonic community collection. The planktonic community was used to assess the protist abundance in the Thau Lagoon, and was provided as a potential food source for the experimental oysters, came from Stn Z (Fig. 1), in the middle of the northern farming area, near the NW bank of the Lagoon (5 $\mathrm{m}$ in depth). Water samples were collected on 17 August 98 from the subsurface $(50 \mathrm{~cm})$, using a $5 \mathrm{l}$ 'Niskin' sampling bottle whose central latex cord had been replaced with silicone tubing and held at field temperature $\left(25^{\circ} \mathrm{C}\right)$ in an opaque carboy until use for the enumeration of protists and for the oyster retention experiment.

Pigment determination. Seawater aliquots (from 30 to $50 \mathrm{ml}$ ) were filtered under a $10 \mathrm{~mm} \mathrm{Hg}$ vacuum through a $2.5 \mathrm{~cm}$ GF/F filter, which was kept in Corning glass tubes at $-20^{\circ} \mathrm{C}$ until extracted. Triplicate filters were ground in $4 \mathrm{ml}$ of $90 \%$ acetone. Samples were stored in the dark at $4{ }^{\circ} \mathrm{C}$ for $24 \mathrm{~h}$, and at the end of the extraction period, the tubes were centrifuged for 10 min at $1200 \times g$. Concentrations of chlorophyll $a$ and pheopigment were measured using a Perkin-Elmer LS50 b spectrofluorometer and pigment amounts calculated according to Neveux \& Lantoine (1993).

Phytoplankton: taxonomy, enumeration and gross growth rates. Seawater triplicates were fixed by formaldehyde ( $4 \%$ final concentration) for microscopic determination of nano-microphytoplankton and enumerated in Utermöhl settling chambers. For flow cytometry analysis of picophytoplankton $(<2 \mu \mathrm{m})$, samples were formaldehyde-fixed $(0.5 \%$ final concentration) and stored in liquid nitrogen, according to Troussellier et al. (1995). Subsamples (200 to $500 \mu l)$ were analyzed with an ACR-1400-SP flow cytometer (Brucker Spectrospin, Wissembourg, France). Picoplanktonic cell sizes were defined by using fluorescent beads (2 $\mu \mathrm{m}$ diameter PolySciences) and controlled by filtration through Nuclepore polycarbonate membranes $(2 \mu \mathrm{m}$ porosity). Cells $>2 \mu \mathrm{m}$ were grouped together as nano- and microphytoplankton up to a diameter of $50 \mu \mathrm{m}$ (upper boundary set by the cytometer). Numeration variability was evaluated from triplicate sample measurements. Standard deviations (SD) were between 1 and $7 \%$ for picoplanktonic numerations and between 5 and $41 \%$ for the largest phytoplanktonic cells; a high value related to their low abun- dance in the sample volume. This variability is similar or slightly lower than that obtained from 5 samples during each experiment: 4 to $11 \%$ for picoplankton in control and grazing experiments and 20 to $35 \%$ for cells greater than $2 \mu \mathrm{m}$ in control experiments.

Phytoplankton gross growth rates and mortality caused by grazing were determined simultaneously in situ at Stn $\mathrm{Z}$ over $24 \mathrm{~h}$ using the dilution technique of Landry \& Hassett (1982) as modified by Landry et al. (1995). No prefiltration was performed, as large diatoms (size greater than $200 \mu \mathrm{m}$ ) were present. Flow cytometry was used to distinguish size classes. The variability was estimated from duplicate samples by the software Statview 4, i.e. $3 \%$ for the gross growth rate and $21 \%$ for grazing mortality.

Ciliates and flagellates: taxonomy and enumeration. Ciliates, dinoflagellates and flagellates were fixed, stained and enumerated according to methods taken from Haas (1982), Caron (1983), and Sherr et al. (1994) and modified by Dupuy et al. (1999). Samples were made in triplicate. The sizes of all cells (length and width) were measured with a calibrated ocular micrometer. The mean cell volume of each taxon was calculated by equating the shape to standard geometric configurations. The cell volume was converted into carbon units using a theoretical carbon/volume ratio of 0.17 pg carbon (C) $\mu \mathrm{m}^{-3}$ (Putt \& Stoecker 1989), and corrected for glutaraldehyde fixative (Leakey et al. 1994). For Tintinnina protists, in addition to enumeration according to the Utermöhl method, counts of individuals retained by a $40 \mu \mathrm{m}$ mesh-size collector were followed by image analysis (Lam-Hoai et al. 1997).

Zooplankton. The large zooplankton were collected from triplicate mixed vertical tows from the $2 \mathrm{~m}$ deep water column, using a $40 \mu \mathrm{m}$ mesh-sized net (input volume: 356 1). Zooplankter counts, size measurements and biovolume estimations were made using an image analysis technique (Lam-Hoai et al. 1997). Cell volume was converted into carbon units as reported above. Zooplankton abundances at Stn Z were evaluated by means of 2 sampling methods: mixed vertical tows from the $2 \mathrm{~m}$ deep water column with a $40 \mu \mathrm{m}$ meshsized net and sampling with $5 \mathrm{l}$ 'Niskin' bottle filtered through the same mesh size. Similar results were obtained: 22 identical taxa out of 30 were identified in both sample types.

Experimental protocol for the study of protist retention by oysters. The possible influence of oyster filtration upon the natural planktonic community was studied by comparing the changes in plankton abundances in triplicate suspensions with and without filtering oysters over $30 \mathrm{~min}$ at ambient temperature $\left(25^{\circ} \mathrm{C}\right)$. At the start of the feeding period, 3 replicate incubations, each containing 1 oyster (mean dry tissue weight $1.86 \pm 0.15 \mathrm{~g}$ ), were assessed; each oyster was trans- 
ferred into an individual $1500 \mathrm{ml}$ round Pyrex tray containing $1300 \mathrm{ml}$ of natural unfiltered Lagoon water from Stn $\mathrm{Z}$ and gently homogenized with a magnetic rod to prevent sedimentation. Two experimental treatments were performed, each in triplicate: suspensions were (1) allowed to evolve as controls, or (2) delivered to actively filtering oysters. Water samples were collected every $5 \mathrm{~min}$ to assess picophytoplankton, nanomicrophytoplankton, flagellate, dinoflagellate and ciliate abundances. Diatoms were enumerated at $t_{0}$ and $t_{15}$ min and large zooplankton abundances at $t_{0}$ and $t_{30} \mathrm{~min}$. It is noteworthy that at the very low natural food concentration used in this study (seston load = $0.65 \mathrm{mg} \mathrm{l}^{-1}$ ), there was no visible production of pseudofaeces. Dry tissue weight of each oyster was recorded at the end of the experiment to express the carbon resource from retained particles per $g$ of oyster dry tissue.

Calculation of specific retention percentages, clearance rates and retained resource. To investigate the occurrence of differential grazing by the oyster among the various taxa of picophytoplankton, nano-microphytoplankton, flagellates, ciliates, and large zooplankton, the percentage of cells retained between 0 and $15 \mathrm{~min}$ was calculated. Clearance rates were estimated for each planktonic type, as previously reported (Dupuy et al. 1999) between 0 and 15 min. During the first $5 \mathrm{~min}$ of the experiment, individual variations in the establishment of regular oyster filtration prevented any reliable study of the protist abundance evolution in the triplicate suspensions. We therefore, selected the subsequent sampling time (15 $\mathrm{min}$ ) as the most appropriate 'standard' time for our clearance experiment. Defined as the theoretical water volume entirely cleared of particles per unit time $\left(\mathrm{l} \mathrm{h}^{-1}\right)$ (Bayne \& Widdows 1978), the clearance rate was calculated according to Coughlan (1969) for the main taxonomic groups from planktonic suspension. Taking into account that weight-specific filtration decreases with increasing body size, standardized clearance rates were calculated according to Riisgård (1988).

The specific contribution of the various planktonic taxa to the particulate resource retained by oysters was expressed as particulate organic carbon (POC) retained per unit time and per $\mathrm{g}$ of oyster dry tissue

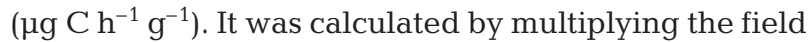
carbon resource of each taxon $\left(\mu \mathrm{g} \mathrm{Cl}^{-1}\right)$ by the corresponding standardized clearance rate $\left(\mathrm{l} \mathrm{h}^{-1} \mathrm{~g}^{-1}\right)$. Initial picophytoplankton, nano-microphytoplankton, diatom, flagellate, dinoflagellate, ciliate and large zooplankton abundances from the triplicate experiments with and without a filtering oyster were compared using a Student's $t$-test (data were previously tested for normality using the Kolmogorov-Smirnov test). Changes in these microbial abundances were followed in triplicate controls during the 30 min experiment by comparing with regression test aliquots sampled at 5 time points $(0,5,10,15$ and $30 \mathrm{~min})$.

\section{RESULTS}

\section{Planktonic resource available}

Taxonomic composition and standing stocks of field microbiota were evaluated in order to estimate the relative contribution of micro-organisms to the POC resource.

\section{Picophytoplankton}

Picophytoplankton was the most abundant autotrophic plankter in the oyster breeding area at the time of our investigation. It was mainly composed of picocells exhibiting the same flow cytometric characteristics as the eukaryotic Ostreococcus tauri, which was the dominant autotrophic taxon in this $<2 \mu \mathrm{m}$ size-class of the Thau Lagoon community during the summer period (Vaquer et al. 1996). The mean abundance of this eukaryotic picophytoplankter was $2.5 \pm 0.3 \times 10^{7}$ cells $\mathrm{l}^{-1}$, which represented more than $97 \%$ of the total autotrophic community density. However, these tiny cells accounted for a very low biovolume $\left(0.52 \mu^{3}\right)$ and a subsequently low carbon cell content ( $\left.0.089 \mathrm{pg} \mathrm{C} \mathrm{cell}{ }^{-1}\right)$.

\section{Diatoms}

The microphytoplankton in August 1998 was mostly composed of large diatoms, such as Rhizosolenia setigera, Lioloma pacificum, Nitzschia longissima and colonial diatoms, such as Pseudo-nitzschia seriata, Thalasionema nitzschioides, Rhizosolenia striata, Skeletonema costatum, Leptocylindricus sp. and several species of Chaetoceros. The average abundance of these algae was $4 \pm 0.8 \times 10^{5}$ cells $\mathrm{l}^{-1}$, the largest contributors being $S$. costatum and Chaetoceros sp. Other taxa (Hemiaulus sp. and Pleurosigma sp.) were scarce. Diatom sizes (Table 1) ranged from $15 \mu \mathrm{m}$ for $S$. costatum up to a maximum value of $541 \mu \mathrm{m}$ for $L$. pacificum. Biovolumes were high and carbon cell contents fluctuated between $\sim 25 \mathrm{pg} \mathrm{C}$ cell $^{-1}$ for Leptocylindrus sp. and $N$. longissima and $\sim 5000 \mathrm{pg} \mathrm{C}$ cell $^{-1}$ for a large diatom, Guinardia striata.

Flagellates, dinoflagellates

The flagellate abundance in the oyster farming area

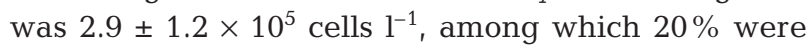


heterotrophic. Cell lengths ranged from 3 to $19 \mu \mathrm{m}$. The dinoflagellate abundance was $1.1 \pm 0.3 \times 10^{4}$ cells $1^{-1}$, with cell sizes ranging from $35.5 \mu \mathrm{m}$ for an unidentified dinoflagellate up to $146 \mu \mathrm{m}$ for Ceratium sp. (Table 2).

\section{Ciliates}

Aloricate ciliates (total abundance $7.2 \pm 2.1 \times 10^{3}$ cells $\mathrm{l}^{-1}$ ) were dominated by the subclass Choreotrichia, mainly represented by the order Haptorida $\left(5.1 \pm 2.2\right.$ cells $\left.\mathrm{l}^{-1}\right)$, the dominant type being Mesodinium sp. Common taxa from the order Oligotrichida (Strombidium sp., $1.8 \pm 1 \times 10^{3}$ cells $\mathrm{l}^{-1}$ ) were also observed. Ciliate sizes ranged from a minimal $12.5 \mu \mathrm{m}$ length for a Mesodinium sp., up to a maximum value of $209 \mu \mathrm{m}$ for Favella sp. (Table 3). Loricate ciliates were mostly represented by Tintinnina with an abundance of $137 \pm 66$ cells $^{-1}$, among which 13 large cells $1^{-1}$ were retained by the $40 \mu \mathrm{m}$ mesh of the zooplankton collector. Tintinnina biovolumes, as well as carbon cell contents, were much higher than for other assemblages (Table 3).

\section{Large zooplankton}

In the farming area (Stn Z), 68 zooplanktonic organisms from 27 identified taxa could be grouped into 5 major groups, arranged in a decreasing order of abundance (Table 4). The total biovolume, estimated by

Table 1. Taxonomic composition, size, biovolume and carbon content of picoeukaryotic cells and microplanktonic diatoms at the Stn Z farming area on 17 August 1998

\begin{tabular}{|c|c|c|c|c|c|c|}
\hline Order & Family & Genus & Species & $\begin{array}{l}\text { Cell length } \\
(\mu \mathrm{m})\end{array}$ & $\begin{array}{l}\text { Biovolume } \\
\left(\times 10^{2} \mu \mathrm{m}^{3}\right)\end{array}$ & $\begin{array}{l}\text { Carbon per cell } \\
\left(\text { pg C cell }{ }^{-1}\right)\end{array}$ \\
\hline Mamiellales & Prasinophyceae & Ostreococcus & tauri & 1 & 0.005 & 0.089 \\
\hline \multirow[t]{4}{*}{ Centrales } & Chaetoceraceae & Chaetoceros & spp. & 18 & 27 & 452 \\
\hline & Rhizosoleniaceae & $\begin{array}{l}\text { Guinardia } \\
\text { Rhizosolenia }\end{array}$ & $\begin{array}{l}\text { striata fa. } \\
\text { setigera fa. }\end{array}$ & $\begin{array}{l}111 \\
460\end{array}$ & $\begin{array}{l}290 \\
253\end{array}$ & $\begin{array}{l}4926 \\
4308\end{array}$ \\
\hline & Melosiraceae & Leptocylindricus & sp. & 24 & 1 & 25 \\
\hline & Thalassiosiraceae & Skeletonema & costatum & 15 & 3 & 45 \\
\hline \multirow[t]{3}{*}{ Pennales } & & Lioloma & pacificum & 541 & 21 & 363 \\
\hline & Nitzschiaceae & $\begin{array}{l}\text { Nitszchia } \\
\text { Pseudonitszchia }\end{array}$ & $\begin{array}{l}\text { longissima } \\
\text { sp. }\end{array}$ & $\begin{array}{r}95 \\
415\end{array}$ & $\begin{array}{r}1 \\
21\end{array}$ & $\begin{array}{r}25 \\
356\end{array}$ \\
\hline & Fragilariaceae & Thalassionema & nitzschioides & 47 & 4 & 73 \\
\hline
\end{tabular}

Table 2. Taxonomic composition, size, biovolume and carbon content of dinoflagellates at the Sth Z farming area on 17 August 1998

\begin{tabular}{|c|c|c|c|c|c|c|}
\hline Order & Family & Genus & Species & $\begin{array}{l}\text { Cell length } \\
(\mu \mathrm{m})\end{array}$ & $\begin{array}{l}\text { Biovolume } \\
\left(\times 10^{3} \mathrm{~m}^{3}\right)\end{array}$ & $\begin{array}{l}\text { Carbon per cel } \\
\quad\left(p g C \text { cell }^{-1}\right)\end{array}$ \\
\hline \multicolumn{7}{|l|}{ Dinophyceae } \\
\hline \multirow[t]{3}{*}{ Peridiniales } & Ceratiaceae & Ceratium & $\mathrm{sp}$. & 146 & 1665 & 283025 \\
\hline & Peridiniaceae & Protoperidinium & sp. & 36 & 12 & 1982 \\
\hline & & Scripsiella & $\mathrm{sp}$. & 32 & 5 & 766 \\
\hline \multirow[t]{3}{*}{ Gymnodiniales } & Gymnodiniaceae & Cochlodinium & sp. & 52 & 8 & 1402 \\
\hline & & Gymnodinium & sp. & 48 & 24 & 4114 \\
\hline & & Gyrodinium & sp. & 50 & 33 & 5628 \\
\hline Dinophysiales & Dinophysiacea & Dinophysis & sp. & 40 & 6 & 968 \\
\hline Ebriales & & Ebria & tripartita & 45 & 12 & 2115 \\
\hline Prorocentrales & Prorocentraceae & Prorocentrum & sp. & 41 & 10 & 1675 \\
\hline \multicolumn{3}{|c|}{ Dinoflagellates unidentified } & & 35 & 26 & 4434 \\
\hline \multicolumn{7}{|c|}{ Euglenophyceae } \\
\hline Eutreptiales & Eutreptiaceae & Unidentified & & 30 & 1 & 234 \\
\hline
\end{tabular}


image analysis, was $47 \times 10^{6}{\mu \mathrm{m}^{3}}^{-1}$. Meroplankton, such as Polychaeta larvae, Cirripeda nauplii and nectobenthic taxa, was almost entirely absent.

\section{Potential planktonic carbon resource}

In order to estimate the potential planktonic resources available for oysters in the farming area, the POC relative to each taxonomic group was estimated. By multiplying for each microbiota the specific carbon cell content by the field abundance, we estimated the relative contribution of each taxon to the total carbon resource of the planktonic community (Table 5). Microplanktonic diatoms, which have large biovolumes, constituted the most important trophic resource
(161.5 $\mu \mathrm{g} \mathrm{C}^{-1}$ ), in spite of their low abundance in the Thau Lagoon on 17 August 1998. Dinoflagellates represented the second most important carbon resource (16.6 $\mu \mathrm{g} \mathrm{C}^{-1}$ ). In contrast, picoeukaryotic cells, with a very small biovolume $\left(0.52 \mu \mathrm{m}^{3}\right)$, accounted for a minimal carbon biomass $\left(2.4 \mu \mathrm{g} \mathrm{C} \mathrm{l}^{-1}\right)$, despite their high field density. Ciliates, flagellates and large zooplankton were not important in terms of biomass in the Thau Lagoon waters at the time of our experiment.

Gross growth rates and grazing mortality of autotrophic plankton was estimated in situ using incubations after dilution manipulations: the subsequent reduction of grazing pressure thereby uncoupling growth and mortality. Small nanophytoplankton exhibited the highest gross growth rate: $3.27 \mathrm{~d}^{-1}$ (Table 6). The gross growth rate of other phytoplankters averaged $2.6 \mathrm{~d}^{-1}$.

Table 3. Taxonomic composition, size, biovolume and carbon content of loricate and aloricate ciliates at the Stn Z farming area on 17 August 1998

\begin{tabular}{|c|c|c|c|c|c|c|c|}
\hline Order & Suborder & Family & Genus & Species & $\begin{array}{l}\text { Cell length } \\
(\mu \mathrm{m})\end{array}$ & $\begin{array}{l}\text { Biovolume } \\
\left(\times 10^{3} \mu^{3}\right)\end{array}$ & $\begin{array}{l}\text { Carbon per cell } \\
\left(\text { pg C cell }^{-1}\right)\end{array}$ \\
\hline \multirow[t]{7}{*}{ Choreotrichida } & \multirow[t]{6}{*}{ Tintinnina } & \multirow[t]{2}{*}{ Codonellidae } & Tintinnopsis & sp. & 37 & 13 & \multirow[t]{2}{*}{2225} \\
\hline & & & Tintinnopsis & corniger & 130 & 71 & \\
\hline & & \multirow[t]{2}{*}{ Tintinnidae } & Eutintinnus & fraknoii & 157 & 116 & \multirow[t]{2}{*}{19777} \\
\hline & & & Eutintinnus & fraknoii & 128 & 56 & \\
\hline & & \multirow[t]{2}{*}{ Ptychocyclidae } & Favella & serrata & 179 & 219 & \multirow[t]{2}{*}{37165} \\
\hline & & & Favella & serrata & 209 & 319 & \\
\hline & \multirow[t]{6}{*}{ Strobilidiina } & Strobilidiidae & Lohmaniella & sp. & 12 & 1 & 174 \\
\hline Oligotrichida & & Strombidiidae & Strombidium & sp. & 47 & 20 & 3479 \\
\hline \multirow[t]{4}{*}{ Haptorida } & & \multirow[t]{3}{*}{ Mesodiniidae } & Askenasia & sp. & 15 & 2 & 348 \\
\hline & & & Mesodinium & $\mathrm{sp}$ & 27 & 3 & 536 \\
\hline & & & Mesodinium & pulex & 12 & & \\
\hline & & Didinnidae & Didinium & $\mathrm{sp}$ & 45 & 36 & 6083 \\
\hline Scuticociliatida & & Unidentified & & & 31 & 6 & 1080 \\
\hline
\end{tabular}

Table 4. Sizes, biovolumes and corresponding resource of the main zooplanktonic taxa $>40 \mu \mathrm{m}$ at the Stn $\mathrm{Z}$ farming area on 17 August 98

\begin{tabular}{|c|c|c|c|c|c|}
\hline Taxa & $\begin{array}{l}\text { Biovolume } \\
\quad(\%)\end{array}$ & $\begin{array}{l}\text { Length } \\
(\mu \mathrm{m})\end{array}$ & $\begin{array}{l}\text { Biovolume } \\
\left(\times 10^{6} \mu \mathrm{m}^{3}\right)\end{array}$ & $\begin{array}{l}\text { Carbon per animal } \\
\quad\left(\text { ng C cell }{ }^{-1}\right)\end{array}$ & $\begin{array}{l}\text { Field } \mathrm{C} \text { resource } \\
\qquad\left(\mu \mathrm{g} \mathrm{C} \mathrm{^{-1 }}\right)\end{array}$ \\
\hline Mostly Bivalvia veligers & 21 & 138 & 0.608 & 85 & 3 \\
\hline \multicolumn{6}{|c|}{$\begin{array}{l}\text { Tintinnina: Favella serrata, Eutintinnus } \\
\text { fraknoii, Tintinnopsis corniger, }\end{array}$} \\
\hline Helicostomella subulata & 7.7 & 195 & 0.271 & 38 & 1 \\
\hline Copepoda nauplii & 9.3 & 172 & 0.346 & 48 & 0.5 \\
\hline $\begin{array}{l}\text { Appendicularia: Oikopleura dioica } \\
\text { Rotatoria: Synchaeta vorax }\end{array}$ & 31.2 & 518 & 0.83 & 116 & 1.4 \\
\hline Trichocerca marina & 6.7 & 191 & 0.454 & 64 & 0.3 \\
\hline Total of main taxa & 100 & 247 & 0.64 & & 6.2 \\
\hline
\end{tabular}


Table 5. Contribution of various taxonomic groups to the planktonic carbon resources available for oysters at the Thau lagoon Stn Z farming area from triplicate samples on 17 August 98

\begin{tabular}{|lrrc|}
\hline & $\begin{array}{c}\text { Abundance } \\
\left(\times 10^{3} 1^{-1}\right)\end{array}$ & $\begin{array}{c}\text { Carbon } \\
\text { resource } \\
\left(\mu \mathrm{g} \mathrm{C} 1^{-1}\right)\end{array}$ & $\begin{array}{c}\text { Contribution } \\
\text { to total POC } \\
(\%)\end{array}$ \\
\hline Picophytoplankton & 25000 & 2.4 & 1.3 \\
Microphytoplankton & 400 & 161.5 & 84.4 \\
$<5 \mu$ flagellates & 207 & 0.6 & 0.3 \\
$>5 \mu$ m flagellates & 87 & 2.3 & 1.2 \\
Dinoflagellates & 11 & 16.6 & 8.7 \\
Ciliates & 7.2 & 3 & 1.6 \\
Zooplankton & 0.07 & 5 & 2.6 \\
Sum & 25712 & 191 & 100 \\
\hline
\end{tabular}

The grazing mortality of picoplankton in a size range between 0.7 and $0.9 \mu \mathrm{m}$ was the highest, with $3.32 \mathrm{~d}^{-1}$. Thus, the whole daily picoplanktonic production was consumed by heterotrophic planktonic grazers $(G / K e=$ 1.29, Table 6).

\section{Retention by oysters of trophic resource cleared from the planktonic microbiota}

\section{Grazing experiments}

The planktonic suspension used for oyster grazing experiments, which was collected subsurface at Stn Z, exhibited a complex taxonomic composition: $2.5 \times 10^{7}$ picophytoplankters $\mathrm{l}^{-1}, 4 \times 10^{5}$ diatoms $\mathrm{l}^{-1}, 2.2 \times 10^{5} \pm$ $2 \times 10^{4}$ flagellates $\mathrm{l}^{-1}, 1.2 \times 10^{4} \pm 3.2 \times 10^{3}$ dinoflagellates $\mathrm{l}^{-1}, 7.4 \times 10^{3} \pm 27 \times 10^{3}$ ciliates $\mathrm{l}^{-1}$, and 68 large zooplankters $\mathrm{l}^{-1}$.

Since all experimental suspensions originated from the same water sample, the initial microbial abundances showed no significant difference between suspensions without (control) or with filtering oysters ( $t$-test, $\mathrm{n}=6, \mathrm{p}>>0.05)$. In the same way, the chlorophyll a concentration was similar at $t_{\mathrm{o}}$ in control sus-

Table 6. Phytoplankton gross growth rate and microzooplankton grazing rates. Data were collected from duplicate experiments

\begin{tabular}{|llll|}
\hline Size class & $\begin{array}{c}\text { Gross growth } \\
\text { rate Ke } \\
\left(\mathrm{d}^{-1}\right)\end{array}$ & $\begin{array}{c}\text { Grazing } \\
\text { mortality } \\
G\left(\mathrm{~d}^{-1}\right)\end{array}$ & G/Ke \\
\hline Picoplankton $(0.7$ to $0.9 \mu \mathrm{m})$ & 2.58 & 3.32 & 1.29 \\
Picoplankton $(1$ to $2 \mu \mathrm{m})$ & 2.64 & 1.6 & 0.61 \\
Nanoplankton $(2$ to $4 \mu \mathrm{m})$ & 3.27 & 0.93 & 0.28 \\
Nanoplankton $(>4 \mu \mathrm{m})$ & 2.65 & 0.83 & 0.31 \\
\hline
\end{tabular}

pensions $\left(1.86 \mu \mathrm{g} \mathrm{l}^{-1}\right)$ and oyster treatments $(1.82 \mu \mathrm{g}$ $\left.\mathrm{l}^{-1}\right)$, and pheophytin initial concentrations were identical in control and oyster trays.

In gently homogenized control suspensions, chlorophyll a concentrations remained constant $\left(1.82 \mu \mathrm{g} \mathrm{l}^{-1}\right)$ until the end of the experiment; similarly, pheophytin concentrations were steady in controls. Abundances of picoeukaryotes, $>2 \mu \mathrm{m}$ phytoplankton, flagellates, dinoflagellates and ciliates remained virtually constant for $30 \mathrm{~min}$ (Fig. 2). The results of regression tests were $\mathrm{r}^{2}=0.204, \mathrm{p} \gg 0.05$ for picoeukaryotes, $\mathrm{r}^{2}=0.18$, $\mathrm{p} \gg 0.05$ for flagellates, $\mathrm{r}^{2}=0.12, \mathrm{p} \gg 0.05$ for dinoflagellates and $\mathrm{r}^{2}=0.0019, \mathrm{p} \gg 0.05$ for ciliates.

In contrast, chlorophyll a concentrations in suspensions with actively filtrating oysters dropped to $0.34 \mu \mathrm{g}$ $\mathrm{I}^{-1}$ at the end of the grazing experiment, i.e. only $18.7 \%$ of the initial concentration. The level of pheophytin increased, probably related to pigment damage resulting from oyster grazing. The abundance of picoeukaryotes was never affected by the presence of oysters during our experiments (Fig. 2a). Changes in the abundance of nano-microplanktonic particles through time are shown in Fig. 2 b-e. Phytoplanktonic cells $>2 \mu \mathrm{m}$ decreased in the triplicate oyster trays, in various ratios according to taxa (mean removal of 80 to $98 \%$ ): most of the largest protists with a size between 12.5 and $540 \mu \mathrm{m}$, diatoms, ciliates, dinoflagellates and large flagellates, were highly retained.

The yield of cells cleared within 15 min in the oyster treatment suspensions was $92 \%$ for microphytoplankton, $94 \%$ for dinoflagellates, and $93 \%$ for ciliates (Fig. 3). Only $44 \%$ of the flagellates were retained. At the end of the experiment (30 $\mathrm{min})$, approximately $90 \%$ of the large zooplankton, all dinoflagellates and ciliates and $55 \%$ of the flagellates had been cleared by the bivalves. Flagellates with a size less than $5 \mu \mathrm{m}$ were poorly $(45 \%)$ retained (Fig. 4$)$.

\section{Clearance rates and carbon resource cleared from planktonic particles}

Particle abundances at 0 and 15 min were also used to estimate oyster clearance rates for each microbiota. The calculation was based on the assumption that abundance decreased exponentially through time in an enclosed suspension volume. Specific clearance rates, i.e. water volume entirely cleared from a specific type of particles per unit time and per oyster dry tissue weight $\left(\mathrm{l} \mathrm{h}^{-1} \mathrm{~g}^{-1}\right)$, were compared among particle types (Table 7). Maximum clearance rates were typical of the most efficiently retained microbiota $\left(16.7 \mathrm{l} \mathrm{h}^{-1} \mathrm{~g}^{-1}\right.$ for $>5 \mu \mathrm{m}$ flagellates, $14.8 \mathrm{l} \mathrm{h}^{-1} \mathrm{~g}^{-1}$ for dinoflagellates). Conversely, clearance rates were low for poorly retained particles $\left(6.8 \mathrm{l} \mathrm{h}^{-1} \mathrm{~g}^{-1}\right.$ for $<5 \mu \mathrm{m}$ flagellates) 


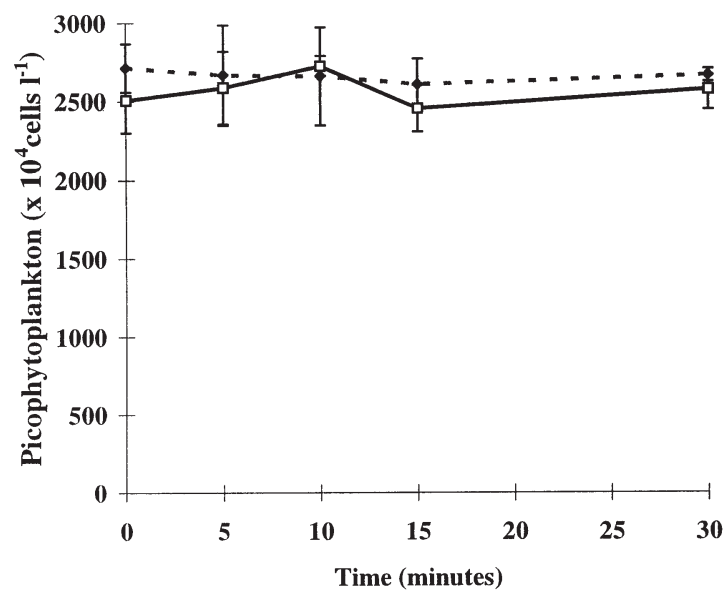

c

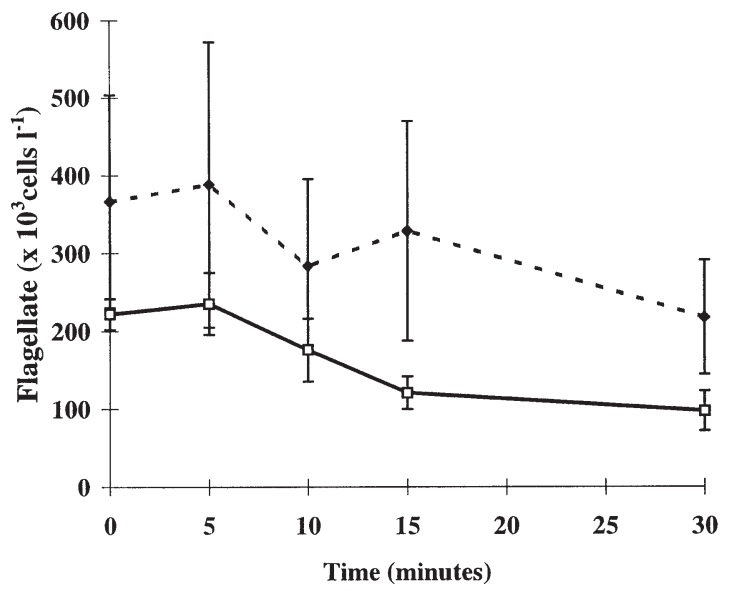

b

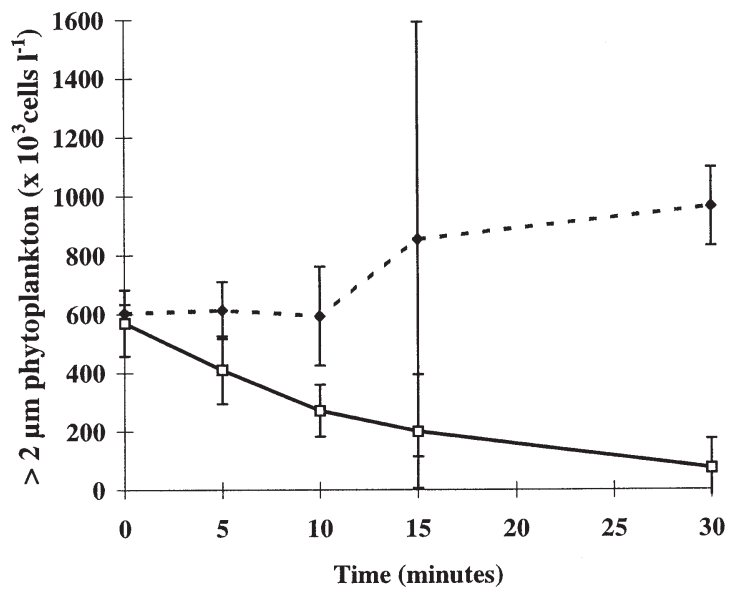

d

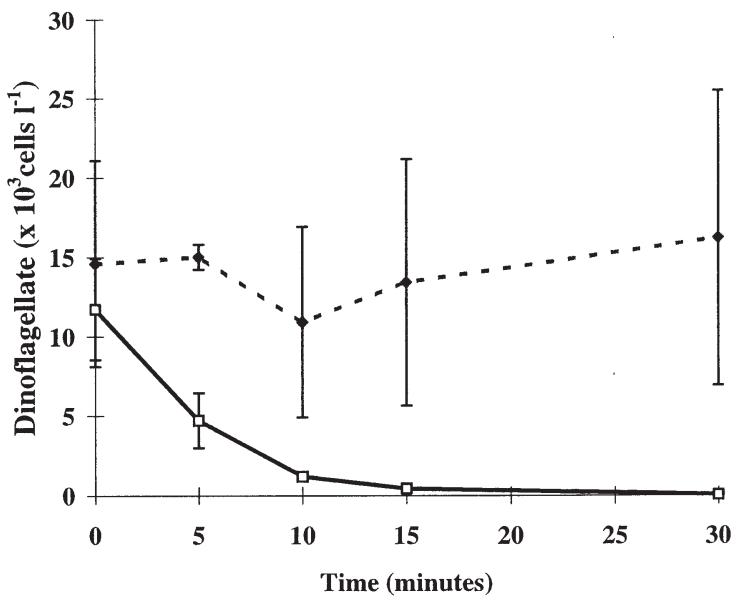

e

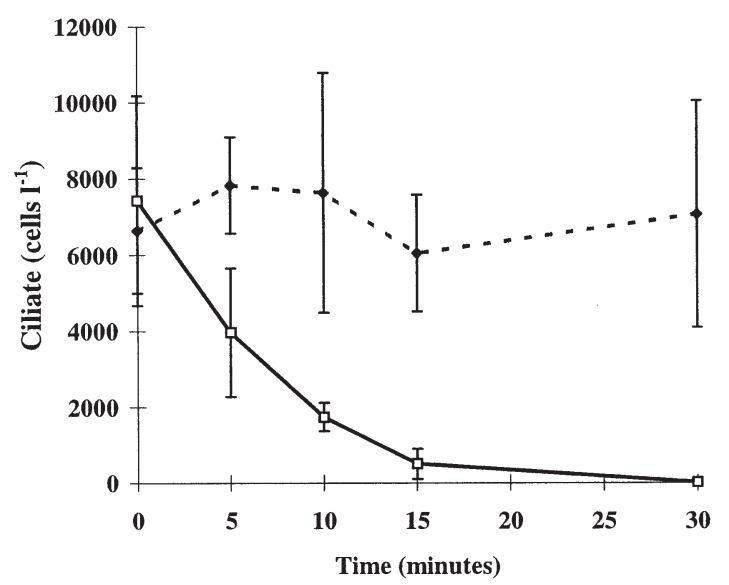

Fig. 2. Retention of various taxa by the oyster Crassostrea gigas. Changes in abundances. (a) Picophytoplankton, (b) $>2 \mu \mathrm{m}$ phytoplankton, (c) flagellates, (d) dinoflagellates and (e) ciliates, in 3 trays without oyster (-- --) or with a filtering oyster ( $-\square-$ ). Abundance data (mean $\pm \mathrm{SD}, \mathrm{n}=3$ ) were collected from 3 replicate incubations with an oyster and 3 replicate incubations with out an oyster performed in $1300 \mathrm{ml}$ lagoon water suspensions 


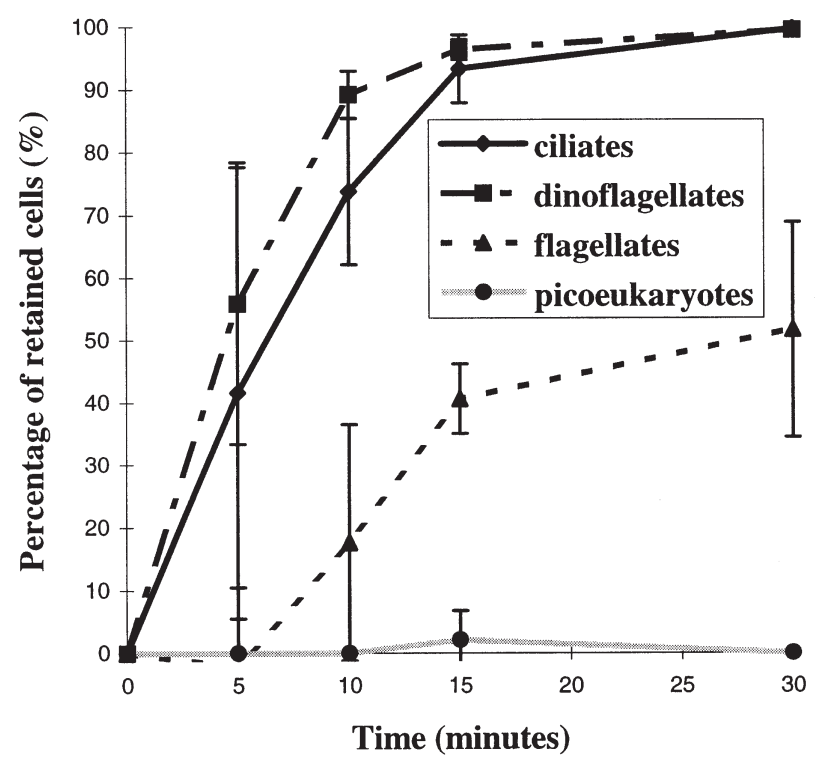

Fig. 3. Percentage of cells retained by filtering oysters for ciliates, dinoflagellates, flagellates and picoeukaryotic cells. Abundance data (mean $\pm \mathrm{SD}, \mathrm{n}=3$ ) were collected from triplicate incubations performed in $1300 \mathrm{ml}$ lagoon water suspensions with a filtering oyster

and close to zero for picoeukaryotes, showing that picoparticles are not retained by oysters. The mean clearance rate for all microbiota $>5 \mu \mathrm{m}$ in size averaged $11.81 \mathrm{~h}^{-1} \mathrm{~g}^{-1}$.

The carbon removed as living planktonic particles by oysters was evaluated from the calculated clearance rate and initial biomasses of microbiota in experimental suspensions. Carbon removal was dependent on the taxon (Table 7 ). The main resource arose from diatoms (81\%) and dinoflagellates (15\%). Ciliates and flagellates contributed poorly to oyster resources, and picoeukaryotic cell contribution was only $0.03 \%$ of the trophic resource in this experiment. The oyster Crassostrea gigas retained on average $1600 \mu \mathrm{g} \mathrm{C} \mathrm{h}{ }^{-1} \mathrm{~g}^{-1}$ from plankton. However, large zooplankton was not taken into account, as the lack of intermediary zooplankton sampling between 0 and $30 \mathrm{~min}$ in our protocol precludes a rigorous estimation of the clearance rate.

\section{DISCUSSION}

The aim of this study was to assess a possible contribution of picoeukaryotes to the food resource intake of the oyster Crassostrea gigas. In the Thau Lagoon, the picoeukaryote Ostreococcus tauri (Prasinophyceae) is the dominant autotrophic picoplankter (Vaquer et al. 1996) with a maximum summer abundance of $2 \times 10^{8}$ cells $^{-1}$ (Chrétiennot-Dinet et al. 1995). Because they are not directly retained by oyster gills, picoeukaryotes might constitute an indirect food resource, transferred to bivalves via heterotrophic protists. Such a trophic link between picoplankton and benthic suspension feeders already has been evidenced in oysters (Le Gall et al. 1997, Dupuy et al. 1999). In order to test this assumption, we have evaluated the planktonic resource in the Thau lagoon and investigated its utilization by oysters.

\section{Trophic resources available in the northern farming area}

Inside the northwestern oyster farming area of the Thau Lagoon (Stn Z), picophytoplankton abundance
Fig. 4. Removal by the oyster Crassostrea gigas of flagellates $>5$ or $<5 \mu \mathrm{m}$ in size. Flagellate abundance data (mean $\pm \mathrm{SD}, \mathrm{n}=3$ ) were collected from triplicate incubations performed in $1300 \mathrm{ml}$ lagoon water suspensions with a filtering oyster

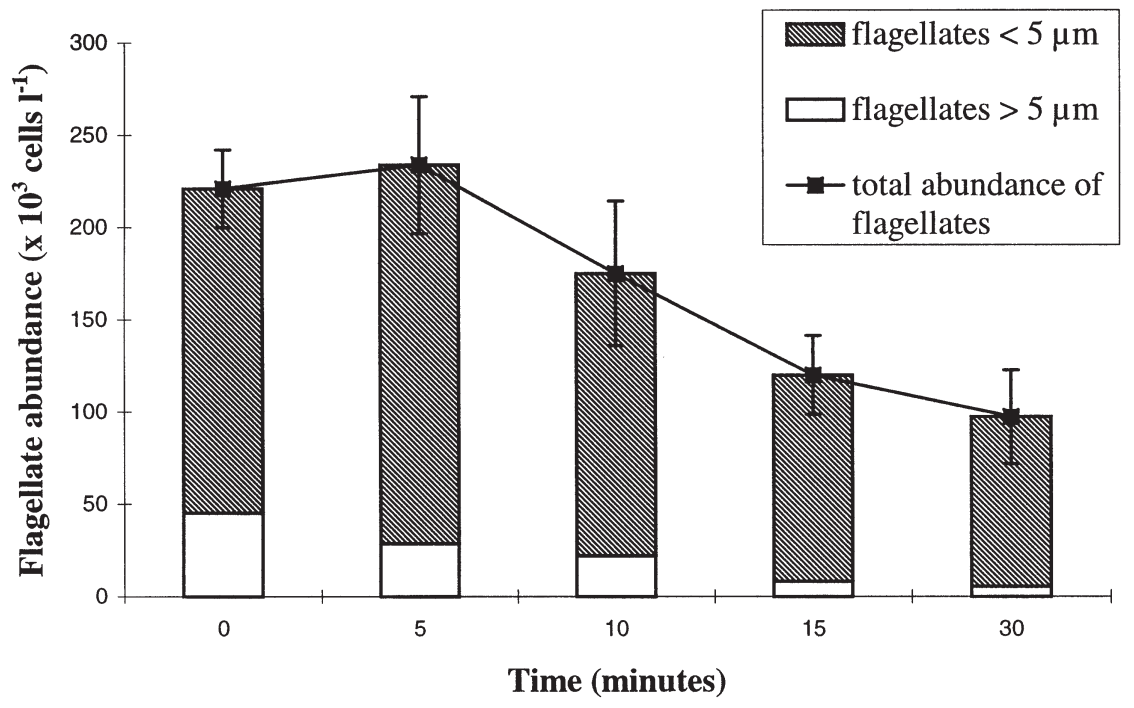


Table 7. Contribution of various taxonomic groups to the particular resource retained by oysters, in the Stn Z farming area of Thau Lagoon in triplicate samples on 17 August 1998. Resource is expressed as POC $\left(\mu \mathrm{g} \mathrm{C} 1^{-1}\right)$. Standardized clearance rate is the theoretical water volume entirely cleared from particles per unit time and standardized per oyster dry tissue weight $\left(1 \mathrm{~h}^{-1} \mathrm{~g}^{-1}\right)$ (Riisgård 1988). Resource and standardized clearance rate were multiplied to estimate the POC resource retained by oysters $\left(\mu \mathrm{g} \mathrm{Ch} \mathrm{h}^{-1} \mathrm{~g}^{-1}\right)$

\begin{tabular}{|c|c|c|c|c|}
\hline & \multicolumn{2}{|c|}{$\begin{array}{c}\text { Standardized clearance } \\
\text { rate }\left(1 \mathrm{~h}^{-1} \mathrm{~g}^{-1}\right)\end{array}$} & \multirow{2}{*}{$\begin{array}{c}\text { POC resource in } \\
\text { the field } \\
\left(\mu g \mathrm{C} \mathrm{l}^{-1}\right)\end{array}$} & \multirow{2}{*}{$\begin{array}{c}\text { POC resource retained } \\
\text { by oysters } \\
\left(\mu \mathrm{g} \mathrm{C} \mathrm{h} \mathrm{h}^{-1} \mathrm{~g}^{-1}\right)\end{array}$} \\
\hline & Mean & $\mathrm{SD}$ & & \\
\hline Picophytoplankton & 0.02 & 0.003 & 2.4 & 0.05 \\
\hline Diatoms & 8.1 & 1.3 & 161.5 & 1307.3 \\
\hline$<5 \mu \mathrm{m}$ flagellates & 6.8 & 6.2 & 0.63 & 4.3 \\
\hline$>5 \mu \mathrm{m}$ flagellates & 16.7 & 4.8 & 2.32 & 38.7 \\
\hline Dinoflagellates & 14.8 & 0.8 & 16.6 & 245.5 \\
\hline Ciliates & 12.7 & 6.1 & 3 & 38.6 \\
\hline Sum & & & 186 & 1634 \\
\hline
\end{tabular}

was $2.5 \times 10^{7}$ cells ${ }^{-1}$ on 17 August 1998. Most of the autotrophic picocells exhibited the same flow cytometric characteristics as the picoeukaryotic Ostreococcus tauri (Courties et al. 1994). Our current abundances are in the range previously observed in the Thau Lagoon, i.e. $3.4 \times 10^{7}$ cells $\mathrm{l}^{-1}$ (Vaquer et al. 1996), but lower than the maximum $10^{8}$ cells $1^{-1}$ densities at the same station in August 1992. Such high levels of picoeukaryotic abundances have been reported elsewhere in the Mediterranean Sea (Magazzù \& Decembrini 1995).

The abundance of the nano-microphytoplankton (i.e. cells $>2 \mu \mathrm{m}$ : diatoms, dinoflagellates and phytoflagellates) inside the oyster farming area was $6.5 \times 10^{5}$ cells $1^{-1}$, a value 7.5 times lower than the mean abundance $\left(5 \times 10^{6}\right.$ cells $\left.\mathrm{l}^{-1}\right)$ previously observed in the Thau Lagoon, and 3 times lower than the previous summer's

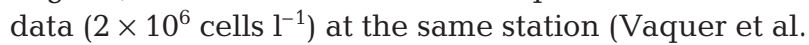
1996). Diatoms were either isolated or chain associated, in a size range between 15 and $541 \mu \mathrm{m}$, constituting $62 \%$ of the nano-microphytoplankters, and Skeletonema costatum (Thalassiosiraceae) was the dominant taxon. Phytoflagellates represented 36.3\% and dinoflagellates only $1.7 \%$ of the nano-microphytoplanktonic community. Among, them $80 \%$ were autoor mixotrophic and $20 \%$ heterotrophic. Their sizes were between 3 and $19 \mu \mathrm{m}$, and their total abundance $\left(2.94 \times 10^{5} \pm 1.2 \times 10^{5}\right.$ cells $\left.1^{-1}\right)$ was low compared to data reported in other environments: the St Lawrence estuary, $1.9 \times 10^{6}$ to $6 \times 10^{6}$ cells $\mathrm{l}^{-1}$ (Lovejoy et al. 1993); Limfjorden marine shallow water, $2 \times 10^{6}$ cells $\mathrm{l}^{-1}$ (Andersen \& Sorensen 1986); and the Parker Estuary, Massachusetts, $>10 \times 10^{6}$ heterotrophic flagellates $\mathrm{l}^{-1}$ (Wright et al. 1987).

As far as we know, the naked ciliate community has not previously been studied in the Thau Lagoon; therefore, we compared our data to results from distant areas. Our estimate of planktonic ciliate abundance (naked ciliates and Tintinninds) in the oyster farming area was $7194 \times 10^{4} \pm 210^{4}$ ciliates $\mathrm{l}^{-1}$. Ciliates were dominated by the order Choreotrichida, with the prevailing Haptorida taxon Mesodinium spp. (5089 \pm 2211 cells $\mathrm{l}^{-1}$ ). Oligotrichida, with the dominant taxon Strombidium spp. $\left(1765 \pm 1054\right.$ cells $\left.\mathrm{l}^{-1}\right)$ had a low abundance compared to high summer densities $(9 \times$ $10^{4}$ cells $\mathrm{l}^{-1}$ ) observed in the Mediterranean Sea (Rassoulzadegan 1977). Tintinnid abundance was $209 \pm$

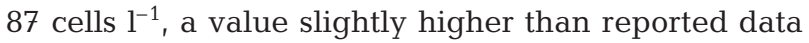
(75 cells $\mathrm{l}^{-1}$ ) from the Thau Lagoon in 1994 (Lam-Hoai et al. 1997). In Mediterranean waters (Villefranchesur-mer Bay), ciliates were much more abundant: $10^{4}$ cells ${ }^{-1}$ (Rassoulzadegan \& Gostan 1976).

The large zooplankton abundance in the oyster farming area was 68000 cells $\mathrm{m}^{-3}$, a value 20 times higher than the mean value in 1994 (Lam-Hoai et al. 1997).

The amounts of potential carbon resources available in the field were estimated for every planktonic microbiota (Table 5). Microphytoplankton was the most

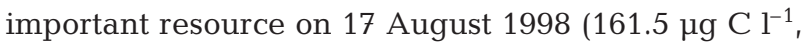
i.e. $84.6 \%$ of the total organic carbon). Dinoflagellates (16.6 $\mu \mathrm{g} \mathrm{C}^{-1}$ ) were the second most important carbon resource. Flagellates $\left(\approx 3 \mu \mathrm{g} \mathrm{C}^{-1}\right)$, ciliates $\left(\approx 3 \mu \mathrm{g} \mathrm{C} \mathrm{l^{-1 } )}\right.$ and zooplankton $\left(\approx 5 \mu \mathrm{g} \mathrm{C}^{-1}\right)$ were not responsible for the trophic richness of the Thau Lagoon waters, and picophytoplanktonic cells represented only $1.3 \%$ of the carbon resource. The ciliate resource in the Thau Lagoon was much lower than elsewhere: ciliates can

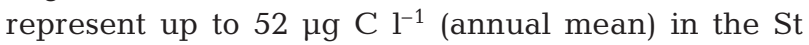
Lawrence Estuary (Sime Ngando et al. 1995) or $63.5 \mu \mathrm{g} \mathrm{C}^{-1}$ (in June 1997) in French Atlantic coastal ponds (Dupuy et al. 1999).

Our estimation of microbiota in the Thau Lagoon and the wide range of previously reported data show the natural variability of picophytoplankton, protist and zooplankton abundances in the field. In terms of 
numerical abundance, the phytoplanktonic community was numerically dominated by picoeukaryotes, but with regard to the carbon resource, microphytoplankton dominated in the Thau Lagoon waters. In recent years, the highest picoeukaryote and nanophytoplankton densities were usually found in summer in the Thau Lagoon, because of favourable environmental factors (Vaquer et al. 1996). Surprisingly, in August 1998, the pico- and nanophytoplankton abundances were not as high as expected, and we observed the development of very large diatoms, probably related to terrestrial nutrient inputs resulting from several rainy days before sampling. However, the retrospective estimation of the picophytoplankton carbon resource in past periods of maximal abundance $\left(10^{8}\right.$ cells $\mathrm{l}^{-1}$ in 1992, Vaquer et al. 1996) results in a weak resource of only $16 \mu \mathrm{C} \mathrm{C} \mathrm{l}^{-1}$. Even during picoeukaryotic bloom events, the main trophic resource would come from microphytoplankton, particularly diatoms.

\section{Utilization by oysters of the planktonic trophic resource}

Grazing experiments were carried out using a natural planktonic population from the northern Thau Lagoon oyster farming area. Chlorophyll $a$, pheopigment concentrations and microbial abundances remained constant in controls. Conversely, chlorophyll a decreased in the oyster grazing experiments (from 1.82 to $0.34 \mathrm{\mu g} \mathrm{l}^{-1}$ ), due to retention of phytoplanktonic cells by oysters; at the same time, pheopigment concentrations increased, perhaps in relation to damage of pigments resulting from oyster grazing. Diatoms (even large species such as Rhizosolenia setigera, Lioloma pacificum), dinoflagellates and ciliates were highly retained by oysters (respectively 92, 96, and 93\%) during grazing experiments. Only $45 \%$ of flagellates (size from 3 to $19 \mu \mathrm{m})$ were cleared. Their retention depended on their size: the smallest flagellates $(<5 \mu \mathrm{m})$, which were also the most abundant, were poorly retained $(\sim 48 \%)$ compared to flagellates with a size $>5 \mu \mathrm{m}$ ( $80 \%$ retained). The fact that picophytoplanktonic abundances were maintained, in both controls and in oyster grazing experiments, was evidence that these tiny particles $(\sim 1 \mu \mathrm{m})$ were not retained by oysters gills. In our experiment, oysters efficiently retained particles larger than $5 \mu \mathrm{m}$ in diameter. Our data agree with previous reports of the known size spectrum of particle retention by oysters filtration: oyster retained less than $10 \%$ of $<1 \mu \mathrm{m}$ particles, more than $50 \%$ of $>3 \mu \mathrm{m}$ particles (DeslousPaoli et al. 1987) and $100 \%$ for $7 \mu \mathrm{m}$ particles in Crassostrea gigas (Héral 1985) and C. virginica (Riisgård 1988); when the sestonic load was low, $100 \%$ of the $4 \mu \mathrm{m}$ particles were retained (Barillé et al. 1993).
The observation of ciliate retention agrees with the previously demonstrated retention by Crassostrea gigas of a cultured ciliate (Le Gall et al. 1997) and of a natural protist community from French Atlantic coastal ponds, with a retention of $94 \%$ for ciliates and $86 \%$ for flagellates (Dupuy et al. 1999). It also corroborates the observations of Paulmier (1972), who reported tintinnids to be abundant in the stomachs of wild oysters from the Atlantic coast.

The mean clearance rate for all microbiota (except picoeukaryotes) averaged $11.8 \mathrm{l} \mathrm{h}^{-1} \mathrm{~g}^{-1}$, a value similar to the estimation calculated according to Riisgård (1988) for an oyster whose weight was $1.86 \mathrm{~g}\left(10.7 \mathrm{l} \mathrm{h}^{-1}\right.$ $\left.\mathrm{g}^{-1}\right)$. The clearance rates of oysters for flagellate, dinoflagellate and ciliate protists were between 12 and $16 \mathrm{l} \mathrm{h}^{-1} \mathrm{~g}^{-1}$ and for diatoms $8 \mathrm{l} \mathrm{h}^{-1} \mathrm{~g}^{-1}$. These values were higher than previously reported clearance rates in water with high sestonic load: $5.71 \mathrm{~h}^{-1} \mathrm{~g}^{-1}$ for Phaeodactylum sp. at high concentration $\left(10^{7}\right.$ cells $\mathrm{l}^{-1}$, i.e. $16 \mathrm{\mu g} \mathrm{C} \mathrm{l}^{-1}$ ) (Fiala-Medioni et al. 1983), $5.5 \mathrm{l} \mathrm{h}^{-1} \mathrm{~g}^{-1}$ for estuary plankton of Marennes-Oléron (Deslous-Paoli et al. 1987), $4.8 \mathrm{l} \mathrm{h}^{-1} \mathrm{~g}^{-1}$ (Bougrier et al. 1997) and $7.8 \mathrm{l}$ $\mathrm{h}^{-1} \mathrm{~g}^{-1}$ (Dupuy et al. 1999). Conversely, with low sestonic loaded waters, clearance rate was $12 \mathrm{l} \mathrm{h}^{-1} \mathrm{~g}^{-1}$ for Phaeodactylum sp. at $10^{6}$ cells $^{-1}$ (Fiala-Medioni et al. 1983) and $16 \mathrm{l} \mathrm{h}^{-1} \mathrm{~g}^{-1}$ for Isochrysis galbana at $1 \times 10^{5}$ cells ${ }^{-1}$, i.e. $0.9 \mathrm{mg} \mathrm{C}^{-1}$ (Walne 1972). These last values are in the range of our current data. Oysters may adjust their clearance rate in oligotrophic conditions. Fiala-Medioni et al. (1983) and Deslous-Paoli et al. (1987) noticed that when the seston load was low, bivalves increased their filtration effort to satisfy their energy requirement.

Our current investigation supports the importance of phytoplankton in oyster nutrition (Héral 1985, Pastoureaud et al. 1996). An evaluation of the retained resource from each taxonomic compartment during grazing experiments was calculated. The highest values of retained resource were from microphytoplankton $\left(1300 \mu \mathrm{g} \mathrm{C} \mathrm{h}^{-1} \mathrm{~g}^{-1}\right)$ at a concentration of $4 \times$ $10^{5}$ cells l $^{-1}$. Fiala-Medioni et al. (1983) estimated that oysters filtering Phaedactylum tricornatum retained about $90 \mu \mathrm{g} \mathrm{C} \mathrm{h} \mathrm{h}^{-1} \mathrm{~g}^{-1}$ for a phytoplankton concentration of $8 \times 10^{6}$ cells $^{-1}$. This difference may result from the greater size and carbon content per cell of diatoms present in the Thau Lagoon in August 1998 (Rhizosolenia setigera contains $4310 \mathrm{pg} \mathrm{C}$ cell $^{-1}$ ) compared to $P$. tricornatum (1.6 pg C cell ${ }^{-1}$ ). Dinoflagellates represented a resource of $245 \mu \mathrm{g} \mathrm{C} \mathrm{h}^{-1} \mathrm{~g}^{-1}$. For ciliates, the retained resource was $39 \mu \mathrm{g} \mathrm{C} \mathrm{h}^{-1} \mathrm{~g}^{-1}$, a value much lower than the $126 \mu \mathrm{g} \mathrm{C}$ ciliates $\mathrm{h}^{-1} \mathrm{~g}^{-1}$ retained by oysters in Atlantic oyster ponds, where ciliates were abundant $\left(2.3 \times 10^{4}\right.$ cells l$\left.^{-1}\right)$ (Dupuy et al. 1999). From the sum of all planktonic partitions, we can estimate that oysters retained $1600 \mu \mathrm{g} \mathrm{C} \mathrm{h}^{-1} \mathrm{~g}^{-1}$. Vaquer et al. (1996) 
previously observed over $1 \mathrm{yr}$ that picophytoplankton abundances were similar inside and outside the oyster farming area. Conversely, they noticed that densities of nano-microphytoplankton, flagellates and zooplanktonic organisms were significantly higher outside the oyster farming area.

Most studies that have examined the nutritional importance of protists as a 'trophic link' have focused on pelagic consumers, such as zooplankton (Berk et al. 1977, Porter et al. 1979, Sherr et al. 1986b, Jonsson \& Tiselius 1990, Gifford \& Dagg 1991); similar experiments on benthic filter-feeding consumers are scarce (Kreeger \& Newell 1996, Le Gall et al. 1997, Dupuy et al. 1999). Trophic coupling between pelagic protists and benthic suspension-feeders is poorly documented in aquatic food models (e.g. see Legendre \& Le Fèvre 1995), although such a relationship could be of primary importance for $\mathrm{C}$ and $\mathrm{N}$ transfer, from the microbial food web to filter-feeder bivalves in benthos (Le Gall et al. 1997). In the Thau Lagoon, the picoeukaryote community (average abundance $3.4 \times 10^{7}$ cells $^{-1}$, Vaquer et al. 1996), constituted the most abundant primary food resource for hetero-/mixotrophic flagellates, dinoflagellates and ciliates. However, because of the small biovolume of their cells, picoeukaryotes only represented $3 \mu \mathrm{g} \mathrm{Cl}^{-1}$. Even during summer bloom events $\left(2 \times 10^{8}\right.$ cells l$^{-1}$, Chrétiennot-Dinet et al. 1995), the picoeukaroyte would only supply the trophic system with a weak available biomass of $16 \mu \mathrm{g} \mathrm{C}^{-1}$. In addition to the low contribution of picophytoplanktonic carbon to Thau lagoon waters in August 1998, picoeukaryotic cells exhibited growth rates of 2.58 to $2.64 \mathrm{~d}^{-1}$ (Table 6), which were lower than for nanoplankton (2.65 to $3.27 \mathrm{~d}^{-1}$ ). These results support the recent speculation of Raven (1994) that for small cells $(<0.9 \mu \mathrm{m})$ there is no increase in maximum specific growth rate with decreasing cell size. Bacteria which represent about $20 \mu \mathrm{g} \mathrm{C}^{-1}$ in the Thau lagoon (M. Trousselier pers. comm.) were also a potential primary food resource for hetero-/mixotrophic flagellates, dinoflagellates and ciliates. Though ciliates exhibit high gross growth efficiencies of $40 \%$ (Ohman \& Snyder 1991), relatively low amounts of picoplanktonic carbon would be recovered by oysters via the protist trophic link.

In conclusion, the Thau Lagoon picoplankton did not represent an important trophic resource for farmed oysters because (1) Crassostrea gigas cannot retain picoparticles and (2) the picoplankton only represented a limited available carbon resource (in terms of biomass) capable of being transferred via a weak protist community. However, this assertion must be moderated because (1) the experiment was only performed once and (2) the productivity of these cells is still not well known, except sporadically (for example in
August of 1988). The measurements with a greatly increased growth rate of Ostreococcus tauri (up to 4.23 divisions $\mathrm{d}^{-1}$ ) were obtained in experimental conditions (Courties et al. 1998). This would suggest an important potential productivity of picophytoplankton. In oyster pens of the Thau Lagoon during August 1998, microphytoplanktonic primary producers, in particular diatoms, could be considered as the main food source for oysters. However, as environmental conditions were exceptional at the time of our experiments (influence of watershed), additional investigations are needed to further identify the energy fluxes available to farmed oysters in the Thau Lagoon.

Acknowledgements. This work was supported by a research grant from IFREMER (No. 973581145) and a doctoral grant from the 'Conseil Général de Charente-Maritime' (Région Poitou-Charentes). We thank the CNRS (UMR CNRS 5556, URM 5, UMR 10), the IFREMER (DEL of Sète), the LBEM (La Rochelle University) and the European Community (MASTIII-DOMTOX), contract MAST-III PL97129 for their financial support. We also thank Voiginie Pons for technical assistance and Mr Robert Knutsen for reviewing the English.

\section{LITERATURE CITED}

Andersen P, Sorensen HM (1986) Population dynamics and trophic coupling in pelagic microorganisms in eutrophic coastal waters. Mar Ecol Prog Ser 33:99-109

Bardouil M, Bohec M, Bougrier S, Lassus P, Truquet P (1996) Feeding responses of Crassostrea gigas (Thunberg) to inclusion of different proportions of toxic dinoflagellates in their diet. Oceanol Acta 19:177-182

Barillé L, Prou J, Héral M, Bougrier S (1993) No influence of food quality, but ration-dependent retention efficiencies in the Japanese oyster Crassostrea gigas. J Exp Mar Biol Ecol 171:91-106

Bayne BL, Widdows J (1978) The physiological ecology of two populations of Mytilus edulis L. Oecologia 37:137-162

Berg JA, Newell RIE (1986) Temporal and spatial variations in the composition of seston available to the suspension feeder Crassostrea virginica. Estuar Coast Shelf Sci 23: 375-386

Berk SG, Brownlee DC, Heinle DR, Kling HJ, Colwell RR (1977) Ciliates as a food source for marine planktonic copepods. Microb Ecol 4:27-40

Bougrier S, Hawkins AJS, Héral M (1997) Preingestive selection of different microalgal mixtures in Crassostrea gigas and Mytilus edulis, analysed by flow cytometry. Aquaculture 150:123-134

Caron DA (1983) Technique for enumeration of heterotrophic and phototrophic nanoplankton, using epifluorescence microscopy, and comparison with other procedures. Appl Environ Microbiol 46:491-498

Chrétiennot-Dinet MJ, Courties C, Vaquer A, Neveux J, Claustre H, Lautier J, Machado C (1995). A new marine picoeucaryote: Ostreococcus tauri gen. et sp. nov. (Chlorophyta, Prasinophyceae). Phycologia 34:285-292

Conover RJ (1982) Interrelations between microzooplankton and other plankton organisms. Ann Inst Oceanogr 58:31-46

Coughlan J (1969) The estimation of filtering rate from the clearance of suspensions. Mar Biol 2:356-358 
Courties C, Vaquer A, Lautier J, Troussellier M, ChrétiennotDinet MJ, Neveux J, Machado C, Claustre H (1994) Smallest eukaryotic organism. Nature 370:255

Courties C, Perasso R, Chretiennot-Dinet MJ, Gouy M, Guillou L, Troussellier M (1998) Phylotgenetic analysis and genome size of Ostreococcus tauri (Chlorophyta, Prasinophyceae). J Phycol 34:844-849

Deslous-Paoli JM, Héral M, Goulletquer P, Boromthanarat W, Razet D, Garnier J, Prou J, Barillé L (1987) Evolution saisonnière de la filtration de bivalves intertidaux dans des conditions naturelles. Oceanis 13:575-579

Dupuy C, Le Gall S, Hartmann HJ, Bréret M (1999) Retention of ciliates and flagellates by the oyster Crassostrea gigas in French Atlantic coastal ponds: protists as a trophic link between bacterioplankton and benthic suspension-feeders. Mar Ecol Prog Ser 177:165-175

Fenchel T (1988) Marine plankton food chains. Annu Rev Ecol Syst 19:19-38

Fiala-Medioni A, Copello M, Colomines JC (1983) Relations trophiques entre huître et milieu; influence de la concentration et de la taille des particules. Bases biologiques de l'aquaculture, IFREMER, Montpellier, p 63-74

Frisoni GF (1984) Contribution à l'étude du phytoplancton dans le domaine paralique. Thèse de docteur-Ingénieur, Université du Languedoc

Gifford DJ, Dagg MJ (1991) The microzooplankton-mesozooplankton link: consumption of planktonic protozoa by the calanoid copepods Acartia clausi Dana and Neocalanus plumchrus Murukawa. Mar Microb Food Webs 5:161-177

Glover HE, Campbell L, Prézelin BB (1986) Contribution of Synechococcus spp. to size-fractioned primary productivity in three water masses in the Northwest Atlantic Ocean. Mar Biol 91:193-203

Goyard E (1995) REMORA, résultats nationaux, année 1994. Rapport IFREMER. Séte

Haas LW (1982) Improved epifluorescence microscopy for observing planktonic microorganisms. Ann Inst Oceanogr 58:261-266

Hartmann HJ, Taleb H, Aleya L, Lair N (1993) Predation on ciliates by the suspension-feeding calanoid copepod Acanthodiaptomus denticornis. Can J Fish Aquat Sci 50: 1382-1393

Héral M (1985) Evaluation of the carrying capacity of molluscan shellfish ecosystems. Aquaculture shellfish culture development and management. International Seminar, La Rochelle 4-9 March 1985. IFREMER, Brest, p 297-318

Jonsson PR, Tiselius P (1990) Feeding behaviour, prey detection and capture efficiency of the copepod Acartia tonsa feeding on planktonic ciliates. Mar Ecol Prog Ser 60:35-44

Kemp PF, Newell SY, Krambeck C (1990) Effects of filterfeeding by the ribbed mussel Geukensia demissa on the water-columm microbiota of a Spartina alterniflora saltmarsh. Mar Ecol Prog Ser 59:119-131

Kreeger DA, Newell RIE (1996) Ingestion and assimilation of carbon from cellulolytic bacteria and heterotrophic flagellates by the mussels Geukensia demissa and Mytilus edulis (Bivalvia, Mollusca). Aquat Microb Ecol 11:205-214

Lam-Hoai T, Rougier C, Lasserre G (1997) Tintinnids and rotifers in a northern Mediterranean coastal lagoon. Structural diversity and function through biomass estimations. Mar Ecol Prog Ser 152:13-25

Landry MR, Hassett RP (1982) Estimating the grazing impact of marine micro-zooplankton. Mar Biol 67:283-288

Landry MR, Kirshtein J, Constantinou J (1995) A refined dilution technique for measuring the community grazing impact of microzooplankton with experimental tests in the central equatorial Pacific. Mar Ecol Prog Ser 20:53-63
Leakey RJG, Burkill PH, Sleigh MA (1992) Planktonic ciliates in Southampton Water: abundance, biomass, production, and role of pelagic carbon flow. Mar Biol 114:67-83

Leakey RJG, Burkill PH, Sleigh MA (1994) A comparison of fixatives for the estimation of abundance and biovolume of marine planktonic ciliate populations. J Plankton Res 16: 375-389

Le Gall S, Bel Hassen M, Le Gall P (1997) Ingestion of a bacterivorous ciliate by the oyster Crassostrea gigas: protozoa as a trophic link between picoplankton and benthic suspension-feeders. Mar Ecol Prog Ser 152:301-306

Legendre L, Le Fèvre J (1995) Microbial food webs and the export of biogenic carbon in oceans. Aquat Microb Ecol 9: $69-77$

Li KW, Subba Rao DV, Harrison GW, Smith CJ, Cullen JJ, Irwin B, Platt T (1983) Autotrophic picoplankton in the tropical ocean. Science 219:292-295

Lovejoy C, Vincent WF, Frenette JJ, Dodson JJ (1993) Microbial gradients in a turbid estuary: application of a new method for protozoan community analysis. Limnol Oceanogr 38:1295-1303

Magazzù G, Decembrini F (1995) Primary production, biomass and abundance of phototrophic picoplankton in the Mediterranean Sea: a review. Aquat Microb Ecol 9: 97-104

Neveux J, Lantoine F (1993) Spectrofluorometric assay of chlorophylls and phaeopigments using the least squares approximation technique. Deep-Sea Res 40:1747-1765

Ohman MD, Snyder RA (1991) Growth kinetics of the omnivorous oligotrich ciliate Strombidium sp. Limnol Oceanogr 36:922-935

Pastoureaud A, Héral M, Prou J, Razet D, Russu P (1996) Particle selection in the oyster Crassostrea gigas (Thunbert) studied by pigment HPLC analysis under natural food conditions. Oceanol Acta 19:79-87

Paulmier G (1972) La nutrition des huitres en relation avec les sources trophiques. Rev Trav Inst Pêches Marit 36: 456-506

Platt T, Subba-Rao DV, Irwin B (1983) Photosynthesis of picoplankton in the oligotrophic ocean. Nature 301:702-704

Porter KG, Pace ML, Battey JF (1979) Ciliate protozoans as links in freshwater planktonic food chains. Nature 277 : 563-565

Putt M, Stoecker DK (1989) An experimentally determined carbon:volume ratio for marine 'oligotrichous' ciliates from estuarine and coastal waters. Limnol Oceanogr 34:1097-1103

Rassoulzadegan F, Gostan J (1976) Répartition des ciliés pélagiques dans les eaux de Villefranche-sur-mer. Remarques sur la dispersion du microzooplancton en mer et à l'intérieur des échantillons dénombrés par la méthode d'Utermöhl. Ann Inst Oceanogr 52:175-188

Rassoulzadegan F (1977) Evolution annuelle des ciliés pélagiques en Méditerrannée nord-occidentale. Ciliés oligotriches 'non tintinnides' (Oligotrichina). Ann Inst Oceanogr 53:125-134

Raven JA (1994) Why are there no picoplanktonic evolvers with volumes less than $10^{-19} \mathrm{~m}^{3}$ ? J Plankton Res 16: 565-580

Revelante N, Gilmartin M (1983) Microzooplankton distribution in the Northern Adriatic Sea with emphasis on the relative abundance of ciliated protozoans. Oceanol Acta 6: 407-415

Riisgård HU (1988) Efficiency of particle retention and filtration rate in six species of North east American bivalves. Mar Ecol Prog Ser 45:217-223

Sherr EB, Sherr BF, Fallon R, Newell SY (1986a) Small alori- 
cate ciliate as a major component of the marine heterotrophic nanoplankton. Limnol Oceanogr 31 (1):177-183

Sherr EB, Sherr BF, Paffenhöfer GA (1986b) Phagotrophic protozoa as food for metazoans: a 'missing' trophic link in marine pelagic food webs? Mar Microb Food Webs 1: 61-80

Sherr EB, Caron DA, Sherr BF (1994) Staining of heterotrophic protists for visualisation via epifluorescence microscopy. In: Kemp PF, Sherr BF, Sherr EB, Cole JJ (eds) Handbook of methods in aquatic microbial ecology. Lewis Publishers, Boca Raton, p 213-227

Shumway SE, Cucci TL, Newell RC, Yentsch CM (1985) Particle selection, ingestion, and absorption in filter-feeding bivalves. J Exp Mar Biol Ecol 91:77-92

Sime-Ngando T, Gosselin M, Roy S, Chanut JP (1995) Significance of planktonic ciliated protozoa in the Lower St. Lawrence Estuary: comparison with bacterial, phytoplankton, and particulate organic carbon. Aquat Microb Ecol 9:243-258

Sournia A, Belin C, Berland B, Erard-Le D, Gentien P, Grze-

Editorial responsibility: John Austin (Assistant Editor), Oldendorf/Luhe, Germany byk D, Marcaillou-Le Baut C, Lassus P, Partensky F (1991) Le Phytoplancton nuisible des Côtes de France. De la biologie à la prévention. IFREMER, Brest

Stoecker DK, Capuzzo JMD (1990) Predation on protozoa: its importance to zooplankton. J Plankton Res 12:891-908

Troussellier M, Courties C, Zettelmaier S (1995) Flow cytometric analysis of coastal lagoon bacterioplankton and picoplankton: fixation and storage effects. Estuar Coast Shelf Sci 40:621-633

Vaquer A, Troussellier M, Courties C, Bibent B (1996). Standing stock and dynamics of picophytoplankton in the Thau lagoon (northwest Mediterranean coast). Limnol Oceanogr 41:1821-1828

Walne PR (1972) The influence of current speed, body size and water temperature on the filtration rate of five species of bivalves. J Mar Biol Assoc UK 52:345-374

Wright RT, Coffin RB, Lebo ME (1987) Dynamics of planktonic bacteria and heterotrophic microflagellates in the Parker Estuary, northern Massachusetts. Cont Shelf Res 7: 1383-1397

Submitted: September 9, 1999; Accepted: February 10, 2000 Proofs received from author(s): September 25, 2000 